\title{
Genotype $\times$ Environment Interactions and Stability Analysis for Seed Yield and Yield Attributing Characters in Castor (Ricinus communis L.)
}

\author{
B.A. Chaudhari*, M.P. Patel, N.V. Soni, A.M. Patel, R.R. Makwana and A.B. Patel
}

Department of Genetics and Plant Breeding, C. P. College of Agriculture, Sardarkrushinagar, Dantiwada Agricultural University, Sardarkrushinagar-385506 (Gujarat), India

*Corresponding author

\section{Keywords}

Stability analysis, G $\mathrm{x}$ E interaction, Grain yield, Castor genotype, Over environments

Article Info

Accepted:

26 April 2019

Available Online:

10 May 2019

\section{A B S T R A C T}

Twenty six genotypes were evaluated for $\mathrm{G} \times \mathrm{E}$ interaction and stability analysis in three environments viz., Castor-Mustard Research Station, S. D. Agricultural University, Sardarkrushinagar $\left(\mathrm{E}_{1}\right)$, Cotton Research Station, S. D. Agricultural University, Talod $\left(\mathrm{E}_{2}\right)$ and Agricultural Research Station, S. D. Agricultural University, Kholwada ( $\left.\mathrm{E}_{3}\right)$ (Gujarat, India) during kharif-rabi 2016-17. The partitioning of $\mathrm{G} \times \mathrm{E}$ interaction were significant for number of effective branches per plant, 100 seed weight, oil content and leaf area, which indicated that the genotypes under study responded differently to the environments. $\mathrm{G} \times \mathrm{E}$ linear component was significantly higher than its counterpart $\mathrm{G} \times \mathrm{E}$ non-linear component for number of effective branches per plant and leaf area. However, for 100 seed weight and oil content non-linear component was higher than linear component, which made them unpredictable. Among the three environments, higher number of effective branches per plant and leaf area was observed under $E_{1}$ location, hence, it was considered as better environment; whereas, less number of effective branches per plant was obtained under $\mathrm{E}_{3}$ location, hence, it was considered as poor environment and $\mathrm{E}_{2}$ location was considered as average environment.

\section{Introduction}

Castor (Ricinus communis L. $2 \mathrm{n}=2 \mathrm{X}=20$ ) is one of the most important non-edible oilseed crop. It belongs to mono specific genus Ricinus of Euphorbiaceae family (Chaudhari et al., 2019). It has cross pollination up to the extent of 50 per cent due to its monoecious nature.

Phenotype is defined as a linear function of Genotype (G), Environment (E) and $\mathrm{G} \times \mathrm{E}$ interaction effects. The study of $G \times E$ interaction serves as a guide for various environmental niches. A particular genotype does not exhibit the same phenotypic expression under different environments and different genotypes respond differently to a particular environment. This variation arising from lack of correspondence between the genetic and non-genetic effects is known as genotype $\times$ environment interaction. The crop yield is dependent on the genotype, environments and their interaction (Pagi et 
al., 2017a,b). When interaction between genotype and environment is present, ranking of genotype will be different under different environments. The plant breeder always interested in the stability of the performance for the characters which are of economically important. The desirable hybrid should have low genotype $\times$ environment interaction for important characters, so as to get desirable performance of hybrids over wild range of environmental conditions. Such hybrids are said to be stable because for their stable performance under changing environments. The presence of $\mathrm{G} \times \mathrm{E}$ interaction is a major problem in getting a reliable estimate of heritability, difficult to predict with a greater accuracy rate of the genetic progress under selection for a given character. Hence, the knowledge of magnitude and nature of $\mathrm{G} \times \mathrm{E}$ interaction is very useful to plant breeders.

The statistical techniques to measure the $G \times$ $E$ interaction developed by Finlay and Wilkinson (1963), Eberhart and Russell (1966) and Perkins and Jinks (1968) have been very useful in breeding programmes. In the present investigation, the approach of Eberhart and Russell (1966) was used to understand the $\mathrm{G} \times \mathrm{E}$ interaction and stability of different genotypes.

\section{Materials and Methods}

Twenty six genotypes of castor were selected for study. The field experiment was conducted at three different location viz., Castor-Mustard Research Station, S. D. Agricultural University, Sardarkrushinagar $\left(\mathrm{E}_{1}\right)$, Cotton Research Station, S. D. Agricultural University, Talod $\left(\mathrm{E}_{2}\right)$ and Agricultural Research Station, S. D. Agricultural University, Kholwada $\left(\mathrm{E}_{3}\right)$ during kharif-rabi 2016-17 with spacing of $120 \mathrm{~cm} \mathrm{X} 60 \mathrm{~cm}$, in RBD with three replications. Standard agronomic practices were followed to raise the crop. The various quantitative traits viz., Days to flowering (primary raceme), Days to maturity (primary raceme), Number of nodes up to the primary raceme, Effective length of primary raceme $(\mathrm{cm})$, Plant height up to primary raceme $(\mathrm{cm})$, Seed yield per plant $(\mathrm{g}), 100$ seed weight $(\mathrm{g})$, Number of capsules on primary raceme, Leaf area $\left(\mathrm{cm}^{2}\right)$ and Oil content (\%) were included for study. Analysis of variance was performed and stability parameters were conducted following the model proposed by Eberhart and Russell (1966). The type of stability was decided on regression coefficient $\left(b_{i}\right)$ and mean values (Finaly and Wilkinson, 1963).

\section{Results and Discussion}

The mean sum of squares due to genotypes was highly significant for all the 11 quantitative characters studied across the environments, which indicated the presence of substantial amount of variation in the material studied. The analysis also indicated significant variation among the environments for all the characters. The values of $\mathrm{G} \times \mathrm{E}$ interaction were significant for number of effective branches per plant, 100 seed weight, oil content and leaf area (Table 1), which indicated that genotypes interacted differently with environmental variations for the said characters. Highly significant values of mean square due to environments (linear) for all the characters indicated that environments differed considerably among different locations. The mean square values due to $\mathrm{G} \times$ $\mathrm{E}$ (linear) and $\mathrm{G} \times \mathrm{E}$ (pooled deviation) were found to be significant for number of effective branches per plant, 100 seed weight, oil content and leaf area.

The stability parameters were worked out and interpreted only for the characters which had significant values of $\mathrm{G} \times \mathrm{E}$ mean square and greater magnitude of $\mathrm{G} \times \mathrm{E}$ (linear) component in respect to pooled deviation i.e. $\mathrm{G} \times \mathrm{E}$ (non-linear), thereby only two 
characters number of effective branches per plant and leaf area were considered for estimation of stability parameters. While, for 100 seed weight and oil content non-linear component (pooled deviation) was higher than linear component, which made genotypes unpredictable and prediction would be biased or less reliable. The stability parameters employed for identification of stable genotype were high or low mean value than population mean, a regression coefficient $\left(b_{i}\right)$ equals to unity and a mean square deviation from regression coefficient statistically equal to zero $\left(\mathrm{S}^{2} \mathrm{di}\right)$.

The higher number of effective branches per plant is desirable for higher seed yield. The results revealed that total 19 genotypes had non significant deviation from regression coefficient and 10 genotypes had higher number of effective branches per plant than mean, out of these, 18 genotypes were identified $\left(b_{i}>1\right.$ and significant: nine and $b_{i}<$ 1 and significant: nine) as well adapted to different environments. Among the genotypes, nine genotypes $\mathrm{GCH}-2, \mathrm{GCH}-7$, SHB-1005, SHB-1019, SHB-1029, GNCH-1, GEETA, 48-1 and JI-96 had below average stability (Mean > genotypes mean; $b_{i}>1$ and $\left.\mathrm{S}^{2} \mathrm{~d}_{\mathrm{i}}=0 \mathrm{NS}\right)$, thereby specifically adapted to favorable environment; while, nine genotypes GAUCH-1, GCH-4, SHB-1018, VP-1, SKI352, SKI-370, SKI-372, SKI-373 and DCS-94 had above average stability (Mean > genotypes mean; $b_{i}<1$ and $\left.\mathrm{S}^{2} \mathrm{~d}_{\mathrm{i}}=0 \mathrm{NS}\right)$, hence specifically adapted to poor environment (Table 2). Higher leaf area is desirable for higher seed yield. The results revealed that total 22 genotypes had nonsignificant deviation from regression coefficient and 10 genotypes had higher leaf area than mean. Out of 26 genotypes, nine genotypes were identified $\left(b_{i}>1\right.$ and significant: seven and $b_{i}<1$ and significant: two) as well adapted to different environments. Among the genotypes, two genotypes GCH-6 and JP-65 had below average stability (Mean > genotypes mean; $b_{i}>1$ and $S^{2} d_{i}=0 \mathrm{NS}$ ), thereby specifically adapted to favorable environment; while, genotypes GCH-4 had above average stability (Mean > genotypes mean; $b_{i}<1$ and $S^{2} d_{i}=0$ NS), hence specifically adapted to poor environment (Table 2).

The results partially confirmed the findings of Henry and Daulay (1985), Tank (2000), Patel (2001), Thakker (2002), Solanki and Joshi (2003), Kumari et al.,(2003), Chaudhari (2006), Patel and Pathak (2006), Sasidharan (2005), Patel et al., (2010), Patel et al.,(2011), Dhedhi et al., (2012) and Patel et al., (2015). However, among the characters under consideration, five characters had higher magnitude of non-linear component (pooled deviation) than its counterpart linear component of $\mathrm{G} \times \mathrm{E}$ interaction; thereby it would not be possible to predict the performance of genotypes for different environments. Further, the significant $\mathrm{G} \times \mathrm{E}$ (linear) component for those characters indicated that the regression coefficients were statically differed and the variation in the performance of genotypes was due to environment induced in genotypes and hence performance of genotypes would be predictable. The results are in agreement with the findings of Henry and Daulay (1985), Thakker (2002), Solanki and Joshi (2003), Chaudhari (2006), Patel and Pathak (2006), Sasidharan (2005) and Patel (2009), Thakker et al., (2010) and Patel (2010). However, pooled deviation variances were significant for number of effective branches per plant, 100 seed weight, oil content and leaf area. The results are also in partial agreement with reports of Patel et al., (1984), Patel (2001), Thakker (2002),Solanki and Joshi (2003), Patel and Pathak (2006), Sasidharan (2005), Patel (2009), Thakker et al., (2010) and Patel (2010). 
Table.1 Analysis of variance for phenotypic stability for different characters

\begin{tabular}{|c|c|c|c|c|c|c|c|c|c|c|c|c|}
\hline $\begin{array}{l}\text { Source of } \\
\text { variation }\end{array}$ & d.f. & $\begin{array}{c}\text { Days to } \\
\text { flowering } \\
\text { (primary } \\
\text { raceme) }\end{array}$ & $\begin{array}{l}\text { Days to } \\
\text { maturity } \\
\text { (primary } \\
\text { raceme) }\end{array}$ & $\begin{array}{c}\text { Number } \\
\text { of nodes } \\
\text { up to } \\
\text { primary } \\
\text { raceme }\end{array}$ & $\begin{array}{c}\text { Seed } \\
\text { yield per } \\
\text { plant }(g)\end{array}$ & $\begin{array}{c}\text { Effective } \\
\text { length of } \\
\text { primary } \\
\text { raceme }\end{array}$ & $\begin{array}{c}\text { Number } \\
\text { of } \\
\text { capsules } \\
\text { in } \\
\text { primary } \\
\text { raceme }\end{array}$ & $\begin{array}{c}\text { Number } \\
\text { of } \\
\text { effective } \\
\text { branches } \\
\text { per } \\
\text { plant }\end{array}$ & $\begin{array}{c}100 \\
\text { seed } \\
\text { weight }\end{array}$ & $\begin{array}{c}\text { Oil } \\
\text { content } \\
(\%)\end{array}$ & $\begin{array}{l}\text { Plant } \\
\text { height } \\
\text { up to } \\
\text { primary } \\
\text { raceme } \\
\text { (cm) }\end{array}$ & $\begin{array}{c}\text { Leaf area } \\
\left(\mathrm{cm}^{2}\right)\end{array}$ \\
\hline Genotypes & 25 & $88.81 * *$ & $123.20 * *$ & $14.43 * *$ & $8868.08 * *$ & $239.95 * *$ & $947.97 * *$ & $14.01 * *$ & $15.83 * *$ & $3600.70 * *$ & $10.55^{* *}$ & $51600913.77 * *$ \\
\hline Environments & 2 & $9.16^{*}$ & $11.34 * *$ & $3.44 * *$ & $3878.20 * *$ & $92.57 * *$ & $239.1 * *$ & $13.91 * *$ & $20.73 * *$ & $406.11 *$ & $7.56^{* *}$ & $73942126.65 * *$ \\
\hline $\mathbf{G} \times \mathbf{E}$ & 50 & 1.13 & 3.58 & 0.43 & 54.48 & 1.67 & 11.89 & $0.24 * *$ & $1.05 * *$ & 46.85 & $0.63 * *$ & $4493594.59 * *$ \\
\hline $\begin{array}{l}\text { Env.+ } \\
\text { (Gen. x Env.) }\end{array}$ & 52 & $1.44 *$ & 3.88 & 0.55 & $201.54 * *$ & $5.17 *$ & 20.63 & $0.77 * *$ & $1.81 * *$ & 60.67 & $0.90 * *$ & $7164691.98 * *$ \\
\hline $\begin{array}{l}\text { Environments } \\
\text { (Lin.) }\end{array}$ & 1 & $18.31 *$ & $22.69 * *$ & $6.87 * *$ & $7756.39 * *$ & $185.13^{* *}$ & $478.2 * *$ & $27.82 * *$ & $41.45^{* *}$ & $812.23 * *$ & $15.13 * *$ & $147884253.30 * *$ \\
\hline G $\times \mathbf{E}$ (Lin.) & 25 & 0.68 & 3.52 & 0.42 & 56.68 & 1.54 & 11.98 & $0.26 * *$ & $0.61 * *$ & 21.52 & $0.42 * *$ & $4775684.78 * *$ \\
\hline $\begin{array}{l}\text { Pooled } \\
\text { Deviation }\end{array}$ & 26 & 1.52 & 3.51 & 0.43 & 50.27 & 1.73 & 11.36 & $0.23 * *$ & $1.44 * *$ & 69.41 & $0.82 * *$ & 4049523.47** \\
\hline Pooled Error & 150 & 0.97 & 6.39 & 0.70 & 248.33 & 3.38 & 12.78 & 0.11 & 0.26 & 96.50 & 0.27 & 1943771.96 \\
\hline
\end{tabular}

$*, * *$ Indicate significant at 0.05 and 0.01 levels, respectively. 
Table.2 Stability parameters of individual genotypes for number of effective branch per plant and leaf area $\left(\mathrm{cm}^{2}\right)$

\begin{tabular}{|c|c|c|c|c|c|c|c|}
\hline \multirow[t]{2}{*}{$\begin{array}{l}\text { Sr. } \\
\text { No. }\end{array}$} & \multirow[t]{2}{*}{ Genotypes } & \multicolumn{3}{|c|}{$\begin{array}{l}\text { Number of effective } \\
\text { branch per plant }\end{array}$} & \multicolumn{3}{|c|}{$\begin{array}{c}\text { Leaf area } \\
\left(\mathrm{cm}^{2}\right)\end{array}$} \\
\hline & & Mean & $\mathbf{b}_{\mathbf{i}}$ & $\mathbf{S}^{2} \mathbf{d}_{\mathbf{i}}$ & Mean & $\mathbf{b}_{\mathbf{i}}$ & $\mathbf{S}^{2} \mathbf{d}_{\mathrm{i}}$ \\
\hline 1 & GAUCH-1 & 5.51 & $0.69 *$ & -0.104 & 9306.60 & $0.67^{*}$ & -1625343.548 \\
\hline 2 & GCH-2 & 8.18 & $1.07 *$ & -0.049 & 9808.60 & 0.08 & $12290286.129 *$ \\
\hline 3 & GCH-4 & 9.18 & $0.98^{*}$ & -0.091 & 17224.95 & $0.99 *$ & -1430140.795 \\
\hline 4 & GCH-5 & 11.82 & 1.37 & $0.733^{*}$ & 9668.86 & -0.44 & 2453512.157 \\
\hline 5 & GCH-6 & 8.87 & 1.15 & 0.267 & 14379.70 & $2.23^{*}$ & -973101.749 \\
\hline 6 & GCH-7 & 14.78 & $1.36^{*}$ & 0.167 & 11644.11 & 0.5 & -786097.617 \\
\hline 7 & SHB-1005 & 10.38 & $1.66^{*}$ & -0.004 & 11606.64 & -0.14 & -1110514.754 \\
\hline 8 & SHB-1018 & 9.00 & $0.92 *$ & -0.099 & 13432.79 & 1.37 & 7994919.588* \\
\hline 9 & SHB-1019 & 12.22 & $1.87 *$ & -0.102 & 11185.60 & 0.67 & 838738.374 \\
\hline 10 & SHB-1029 & 11.12 & $2.28 *$ & 0.062 & 18167.63 & 0.52 & $14501160.418 *$ \\
\hline 11 & GNCH-1 & 10.44 & $1.14 *$ & 0.157 & 17221.76 & 0.56 & 1073294.173 \\
\hline 12 & VP-1 & 5.64 & $0.57 *$ & -0.072 & 8650.98 & 0.45 & -1098805.252 \\
\hline 13 & GEETA & 11.29 & $1.18^{*}$ & 0.198 & 17163.74 & 0.67 & -437091.315 \\
\hline 14 & JP-65 & 7.84 & 0.55 & 0.082 & 13886.30 & $1.13^{*}$ & -1188305.792 \\
\hline 15 & SKP-84 & 8.31 & 0.75 & $0.376^{*}$ & 9394.85 & 0.92 & 1989221.447 \\
\hline 16 & VI-9 & 7.53 & 0.76 & $1.011^{*}$ & 16702.53 & -0.67 & 4897793.701 \\
\hline 17 & JI-35 & 8.76 & 0.29 & 0.031 & 8654.87 & $1.8^{*}$ & 2026587.796 \\
\hline 18 & $48-1$ & 11.36 & $1.59^{*}$ & 0.234 & 27104.32 & 2.9 & 12073768.38* \\
\hline 19 & SH-72 & 8.47 & 0.47 & $0.405^{*}$ & 8974.80 & -0.42 & -35226.164 \\
\hline 20 & JI-96 & 8.07 & $1.19 *$ & 0.143 & 10722.39 & 0.96 & -69516.695 \\
\hline 21 & SKI-215 & 9.71 & 0.51 & $0.351 *$ & 12281.03 & $2.04 *$ & -820716.022 \\
\hline 22 & SKI-352 & 8.98 & $0.78 *$ & -0.101 & 10830.72 & 1.79 & 4626879.936 \\
\hline 23 & SKI-370 & 8.18 & $0.96^{*}$ & -0.091 & 10624.09 & $1.73^{*}$ & -1746194.105 \\
\hline 24 & SKI-372 & 7.49 & $0.66^{*}$ & -0.073 & 11532.73 & 1.89 & 4662457.198 \\
\hline 25 & SKI-373 & 10.73 & $0.70 *$ & -0.069 & 13182.15 & $1.61^{*}$ & -1586709.844 \\
\hline 26 & DCS-94 & 5.67 & $0.55^{*}$ & -0.05 & 10112.52 & $2.18^{*}$ & -1771316.295 \\
\hline \multicolumn{2}{|c|}{ General mean } & 9.21 & - & - & 12825.59 & - & - \\
\hline
\end{tabular}

In conclusion, for number of effective branches per plant, genotypes $\mathrm{GCH}-2, \mathrm{GCH}-$ 7, SHB-1005, SHB-1019, SHB-1029, GNCH1, GEETA, 48-1 and JI-96 had below average stability $\left(b_{\mathrm{i}}>1\right)$ and specifically adapted to favourable environment. Among genotypes, GAUCH-1, GCH-4, SHB-1018, VP-1, SKI352, SKI-370, SKI-372, SKI-373 and DCS-94 had above average stability $\left(b_{i}<1\right)$ and well adapted to unfavorable environment. Genotypes, GCH-6, JP-65, JI-35, SKI-215, SKI-370, SKI-373 and DCS-94 had below average stability for leaf area $\left(b_{i}>1\right)$ and specifically adapted to favourable environment. Among genotypes, GAUCH-1 and $\mathrm{GCH}-4$ had above average stability $\left(\mathrm{b}_{\mathrm{i}}<\right.$ 1) and well adapted to unfavorable environment for leaf area. 
Out of the three environments, higher number of effective branches per plant and leaf area was observed under $\mathrm{E}_{1}$ location, hence it was considered as better environment; whereas, less number of effective branches per plant was obtained under $\mathrm{E}_{3}$ location hence, it was considered as poor environment and $\mathrm{E}_{2}$ location was considered as average environment.

\section{References}

Baker, R.J.H. (1969). Genotype × Environment interactions in yield of wheat. Journal of Plant Science. 49: 743-751.

Chaudhari, B.A., Patel, M.P., Dharajiya, D.T. and Tiwari, K.K. (2019). Assessment of genetic diversity in castor (Ricinus communis L.) using microsatellite markers. Biosciences Biotechnology Research Asia, 16(1): 61-69. DOI: http://dx.doi.org/10.13005/bbra/2721.

Chaudhari, K.N. (2006). Diallel analysis for seed yield and wilt resistance in castor (Ricinus communis L.). Ph.D. Thesis (Unpublished), submitted to Sardarkrushi nagar Dantiwada Agricultural University, Sardarkrushinagar (Gujarat State).

Dhedhi, K.K., Joshi, H.J. and Dangaria, C.J. (2012). Phenotypic stability in castor. Punjab Rao Deshmukh Krushi Vidhyapeeth. Research Journal. 36 (1): 1-4.

Eberhart, S.A. and Russell, W.L. (1966). Stability parameters for comparing varieties. Crop Science. 6: 36-40.

Finlay, K.W. and Wilkinson, G.N. (1963). The analysis of adaptation in plant breeding programme. Australian Journal of Agricultural Research. 14: 742-754.

Henry, A. and Daulay, H.S. (1985). Genotype $\times$ Environment interactions for seed yield in castor bean. Madras
Agricultural Journal. 72 (4): 196-198.

Kumari, T.R.; Subramanyam, D. and Sreedhar, N. (2003). Stability analysis in castor (Ricinus communis L.). Crop Research. 25: 96-102.

Pagi, N., Dharajiya, D., Ravindrababu, Y., Pachchigar, K., Soni, N., Parmar, L., Patel, J., Chauhan, R. and Patel, M. (2017a). Phenotypic stability and GGE biplot analysis in pigeonpea [Cajanus cajan (L.) Millsp.] genotypes across the environments. Journal of Experimental Biology and Agricultural Sciences, 5(3): 359-367. DOI: http://dx.doi.org/10. 18006/2017. 5(3): 359.367.

Pagi, N., Prajapati, N., Pachchigar, K., Dharajiya, D., Solanki, S.D., Soni, N. and Patel, P. (2017b). GGE biplot analysis for yield performance of grain amaranth genotypes across different environments in western India. Journal of Experimental Biology and Agricultural Sciences, 5(3): 368-376. DOI: http://dx.doi.org/10.18006/2017. 5(3): 368.376 .

Patel, A.A. (2001). Line $\times$ tester analysis over environments in castor (Ricinus communis L.). Ph.D. Thesis (Unpublished), submitted to Gujarat Agricultural University, Sardarkrushinagar (Gujarat State).

Patel, A.R. (2009). Genetic analysis of seed yield and component characters over environments in castor (Ricinus communis L.). Ph.D. Thesis (Unpublished), submitted to Anand Agricultural University, Anand (Gujarat State).

Patel, C.M., Patel, J.M. and Patel, C.J. (2015). Gene $\times$ Environment interaction and stability analysis for yield and yield determinant traits in castor (Ricinus communis L). IOSR Journal of Agriculture and Veterinary Science. 8 (6): 68-72.

Patel, D.K., Ravindrababu, Y. and Patel, P.J. 
(2011). Genotype × Environmental interaction and stability parameters for yield and component characters in castor (Ricinus communis L.) International Journal of Forestry and Crop Improvement. 2 (1): 64-67.

Patel, I.D., Dangaria, C.J., Dholaria, S.J. and Patel, V.J. (1984). Phenotypic stability of seed yield in eight hybrids of castor. Indian Journal of Agricultural Sciences. 54 (8): 629-632.

Patel, J.A., Patel, B.N., Patel, A.R. and Kumar, R. (2010). Genotype $\times$ Environment interaction and stability parameters for yield and component characters in castor (Ricinus communis L.). Journal of Oilseeds Research. 2: 47-49.

Patel, J.B. and Pathak, H.C. (2006). Genotype $\times$ Environment interaction and stability parameters in castor (Ricinus communis L.). Journal of Oilseeds Research. 23 (1): 35-38.

Perkins, J.M. and Jinks, J.L. (1968). Environmental and genotype environmental components of variability III. Multiple lines and crosses. Heredity. 23: 339-356.

Sasidharan, N. (2005). Genetic analysis for yield and quality in castor (Ricinus communis L.) under diverse environments. Ph.D. Thesis (Unpublished), submitted to Anand Agricultural University, Anand (Gujarat).

Solanki, S.S. and Joshi, P. (2003). Phenotypic stability of hybrids and parents for seed yield and its components in castor (Ricinus communis L.). Journal of Oilseeds Research. 20 (1): 45-47.

Sprague, G.F. (1966). Quantitative Genetics in Plant Improvement. In: Plant Breeding. A symposium held at the Iowa State University (Ed. K.J. Frey). pp. 351-354.

Tank, C.J. (2000). Diallel analysis over environments in castor (Ricinus communis L.). Ph.D. Thesis (Unpublished), submitted to Gujarat Agricultural University, Sardar krushinagar (Gujarat).

Thakker, D.A. (2002). Heterosis and combining ability studies in castor (Ricinus communis L.). Ph.D. Thesis (Unpublished), submitted to Gujarat Agricultural University, Sardar krushinagar (Gujarat).

Thakker, D.A., Gami, R.A. and Patel, P.S. (2010). $\mathrm{G} \times \mathrm{E}$ and stability studies on castor hybrids for yield and its attributing characters. Journal of Oilseeds Research, 27: 74-77.

\section{How to cite this article:}

Chaudhari, B.A., M.P. Patel, N.V. Soni, A.M. Patel, R.R. Makwana and Patel, A.B. 2019. Genotype $\times$ Environment Interactions and Stability Analysis for Seed Yield and Yield Attributing Characters in Castor (Ricinus communis L.). Int.J.Curr.Microbiol.App.Sci. 8(05): 2475-2481. doi: https://doi.org/10.20546/ijcmas.2019.805.292 